\title{
Aspects of human brucellosis
}

\author{
P. G. MANN \\ M.D., M.R.C.Path., Dip. Bact. \\ Public Health Laboratory, Bath
}

\author{
ElizABETH R. RichenS \\ Ph.D.
}

University of Bath

\begin{abstract}
Summary
Human brucellosis still presents difficulties in diagnosis and prevention. Townspeople may be infected by drinking raw milk while on holiday. Laboratory tests are still unsatisfactory as indicators of clinically active disease. High titre antibodies may be found without overt symptoms, particularly in persons occupationally exposed to repeated infection. In contrast, cases have been recorded in which no antibody appeared despite a positive blood culture. A preliminary study of leukocyte migration inhibition suggests that this may prove useful in detecting disease associated with low or absent antibodies, but is not likely to provide an infallible guide to clinical activity.
\end{abstract}

THE history of a case recently encountered exemplifies many of the problems currently raised by human brucellosis.

A young man of 20 was admitted to hospital in July 1972 with a fever of 2 weeks duration. A diagnosis of subacute bacterial endocarditis was seriously considered, for at the age of 9 open-heart surgery had revealed a ventricular septal defect. This had not been repaired. Repeated blood cultures proved negative. Inquiry revealed that the patient, who lived near Southend and normally drank only heat-treated milk, had drunk raw milk while on holiday in May. A brucella agglutination test was positive at a titre of $1 / 2500$. Treatment with tetracycline was followed rapidly by recovery. A course lasting 3 weeks was given and by August the patient was reported to be well.

Exposure to raw milk occurred when travelling by road through Somerset to Devon and Cornwall. The patient and two companions stayed overnight on a farm where two cows were kept to supply the household with fresh milk. The cows had been bought when in calf rather over 2 years before. One had subsequently produced a viable calf, whereas the other aborted. Tests for brucellosis at that time were said to be negative and both cows subsequently produced further healthy calves. Milk from each cow was sampled in September 1972 and both samples yielded Brucella abortus, biotype 1, on culture. The farmer has since accepted advice that milk from these cows must be heated adequately before consumption. The patient's two travelling companions have remained well.

Several features of this case are particularly significant.

(1) Laboratory evidence of brucella infection rested solely on serology. Assessment of activity meriting specific chemotherapy depended on clinical findings and the exclusion of alternative diagnoses, such as bacterial endocarditis.

(2) Treatment with tetracycline was followed promptly by clinical recovery.

(3) Public health inquiries revealed an infected milk-supply, without necessarily having excluded the possibility of other sources elsewhere on the patient's holiday itinerary. The farmer concerned accepted simple advice which should protect his family and future visitors from the risk of infection.

(4) The earlier history of the two cows shows the ease with which bovine infection can escape detection. It is an established fact that cows without demonstrable serum agglutinins can abort, yet subsequently produce healthy calves while yielding infected milk.

(5) Townsfolk and others normally protected by the provision of safe, heat-treated milk may acquire infection by exposure to raw milk while on holiday in the country or travelling abroad.

(6) The experience of the patient's travelling companions illustrates once more how, in brucellosis as in many other infective diseases, by no means all those exposed to infection will develop overt disease.

(7) The episode provides an example of the 'short and only possible exposure' so successfully identified and applied by Wilfred Pickles to determining the incubation period of an infection. In this case the interval from exposure to onset of fever was about 7 weeks.

When considering brucellosis it is important to distinguish clearly two modes of diagnosis. On the one hand is the determination whether at some time the patient has been infected by the organism, on the other lies the decision whether a train of symptoms is due to currently active infection and can be expected to respond to appropriate chemotherapy. Both approaches are apt to be described as diag- 
nosis of the infection, but their ends and means are different. It is usually difficult to produce complete proof that symptoms are due to active brucella infection, but patients, as the late Dr Hugh Wallis was apt to remark, come for the relief of their ailments.

If a patient has been treated successfully on the basis of reasonably high probabilities a main aim has been achieved. If, as well, inquiry has brought to light an unsuspected source of infected milk against which the public is subsequently protected, these defects in the logical chain of diagnostic reasoning begin to seem less distressing.

In the United Kingdom laboratory evidence of Br. abortus infection still rests mainly on serology. Positive blood cultures are found in only a minority of cases, usually those due to biotype 1 . Henderson \& Hill (1972) have published an important summary of the evidence that high serum antibody titres are not a reliable index of active infection. Painstaking surveys among veterinarians and the farming community have produced many examples of individuals who are symptomless despite the presence of high-titre antibody.

There are grounds also for asserting that circulating antibody may be absent or of low titre, in the presence of currently active disease. Payne (1972) has described a patient with clinically active brucellosis and a positive blood culture without any demonstrable serum antibodies. Careful clinicians have reached similar conclusions, although lacking the crucial evidence of positive blood culture. Wallis (1959) published a detailed account of children in whom the final diagnosis was considered to be $B r$. abortus infection. Thirty of these children had saline agglutinin titres of less than 1/20 when first seen. Among cattle it has long been known that continuing infection, as established by post-mortem examination or milk culture, may be present without detectable serum antibody.

The clinical laboratory is confronted with the twin problems of detecting infection in the occasional absence of antibody, and assessing the activity of infection in relation to current ill-health. Tests for agglutinins, complement fixing or even incomplete antibody have little to offer in the assessment of activity, particularly when there is occupational exposure to infection, and may even be misleading in the exclusion of brucellosis as a diagnosis. Paired sera may occasionally be fortuitously available to establish a diagnosis of current brucellosis as in the case of many other acute infections, but the approach is of severely limited value in a disease of insidious onset which is hard to suspect, let alone recognize, before many months have passed and a pattern of episodic ill-health has emerged. The rapid decay of antibody following successful treatment may provide useful additional support for a retrospective diage nosis, but patients are likely to receive, as well treatment, advice on the avoidance of future infection. It is difficult to be certain how far a decline in antibody stems from elimination of the organism by chemotherapy and how far it may be caused b the patient no longer receiving repeated antigen stimuli from contact with a source of infection.

In this context it has seemed worth examining the value of the leukocyte migration inhibition test in the investigation of human brucellosis. Soborg (1970 1971) has reported a correlation between human skin sensitivity to brucellin and inhibition of leukos cyte migration in presence of $\mathrm{Br}$. abortus antigen. Pearson, Scarfe \& Morgan (1973) have suggested that some patients with active brucellos may show marked brucellin sensitivity, while havin 8 little or no circulating antibody. A start has beein made upon a comparative study of symptomatologye brucella agglutinins, complement-fixing antibods and the leukocyte migration inhibition index Patients are assessed in consultation with thei general practitioner and by personal interview, whe $\vec{n}$ signs and symptoms likely to relate to brucellosis are recorded systematically and heparinized blood taken for a leukocyte migration test and serology? The serological tests comprise agglutination phenol-saline (Report, 1961) and in 2-mercaptow ethanol, together with a complement fixation The leukocyte migration is based on the method of Soborg, using Br. abortus antigen (Standard Laboratory, Central Public Health Laboratory Colindale) at a concentration of 50 millio organisms $/ \mathrm{ml}$. Results are expressed as percentages calculated from the ratio between the area of migra tion in presence of antigen and the area of migration in an antigen-free control. Normal values range from $80-120$, with a relative standard error of 5.8 (Takeshi Yoshida, Janeway \& Paul, 1972). Th results obtained to date from seventeen patients aro shown in the accompanying tables.

Only tentative observations can be offered on the observations so far available. In Table 1, relating to cases without evidence of leukocyte migratiog inhibition, it is interesting to note case 9 as an example of high titre antibody without over. symptoms of brucellosis. This patient is also of interest as an instance of high-titre antibody without evidence of cellular immunity. In Table 2 , cases 30 5,11 , and 14 show that cellular immunity may be present despite the virtual absence of circulating antibody. On clinical grounds, cases 3,5 , and 16 could not be regarded as having active brucellosis although cases 5 and 11 had certainly been in contact with infected cattle in the fairly recent past. It would seem that leukocyte migration inhibition is unlikel to provide an objective laboratory test for assessing 
TABLE 1. Ten cases with negative leukocyte migration test

\begin{tabular}{|c|c|c|c|c|c|}
\hline $\begin{array}{l}\text { Case } \\
\text { no. }\end{array}$ & $\begin{array}{c}\text { Clinical } \\
\text { assessment }\end{array}$ & Occupation & $\begin{array}{c}\text { Serum antibody } \\
\text { titres } \\
\text { (saline/2ME/CF) }\end{array}$ & $\begin{array}{l}\text { LMI } \\
\text { index }\end{array}$ & $\begin{array}{c}\text { Relative } \\
\text { SE }\end{array}$ \\
\hline $\begin{array}{l}1 \\
2\end{array}$ & $\begin{array}{l}\text { Not brucellosis } \\
\text { Treated } \\
\text { brucellosis }\end{array}$ & $\begin{array}{l}\text { Physician } \\
\text { Knackerman }\end{array}$ & $\begin{array}{l}<20 / \mathrm{NT} /<4 \\
<20 / \mathrm{NT} /<4\end{array}$ & $\begin{array}{r}88 \\
101\end{array}$ & $\begin{array}{r}8 \cdot 7 \\
20 \cdot 5\end{array}$ \\
\hline 4 & Not brucellosis & Farmer & $80 / 40 /<4$ & 112 & $3 \cdot 1$ \\
\hline 6 & Not brucellosis & $\begin{array}{l}\text { Veterinary } \\
\text { technician }\end{array}$ & $<20 / \mathrm{NT} / 32$ & 80 & $2 \cdot 8$ \\
\hline 9 & Not brucellosis & Farmer & $1280 / 1280 / 256$ & 83 & $6 \cdot 1$ \\
\hline 10 & Not brucellosis & Farmer & $<20 / \mathrm{NT} /<4$ & 96 & $3 \cdot 0$ \\
\hline 12 & Not brucellosis & $\begin{array}{l}\text { Operating } \\
\text { theatre } \\
\text { assistant }\end{array}$ & $<20 / \mathrm{NT} /<4$ & 95 & $6 \cdot 3$ \\
\hline 15 & Not brucellosis & Caterer & $<20 / \mathrm{NT} /<4$ & 111 & $11 \cdot 4$ \\
\hline 16 & Not brucellosis & Housewife & $<20 / \mathrm{NT} /<4$ & 109 & 10.9 \\
\hline 17 & Not brucellosis & $\begin{array}{l}\text { Business } \\
\text { executive }\end{array}$ & $<20 / \mathrm{NT} /<4$ & 109 & $14 \cdot 8$ \\
\hline
\end{tabular}

TABle 2. Seven cases with positive leukocyte migration test

\begin{tabular}{cllccc}
\hline $\begin{array}{c}\text { Case } \\
\text { no. }\end{array}$ & $\begin{array}{c}\text { Clinical } \\
\text { assessment }\end{array}$ & Occupation & $\begin{array}{c}\text { Serum antibody } \\
\text { titres } \\
\text { (saline/2ME/CF) }\end{array}$ & $\begin{array}{c}\text { LMI } \\
\text { index }\end{array}$ & $\begin{array}{c}\text { Relative } \\
\text { SE }\end{array}$ \\
\hline 3 & Not brucellosis & Housewife & $<20 / \mathrm{NT} /<4$ & 76 & $7 \cdot 3$ \\
5 & Not brucellosis & Housewife & $<20 / \mathrm{NT} /<4$ & 62 & $3 \cdot 5$ \\
7 & Acute brucellosis & Farmer & $160 / 160 / 16$ & 57 & $8 \cdot 5$ \\
8 & $\begin{array}{c}\text { Relapsing } \\
\text { brucellosis }\end{array}$ & $\begin{array}{c}\text { Veterinary } \\
\text { surgeon }\end{array}$ & $160 / 160 / 64$ & 51 & $2 \cdot 2$ \\
11 & $\begin{array}{l}\text { Not brucellosis } \\
\text { Relapsing }\end{array}$ & $\begin{array}{c}\text { Student } \\
\text { Veterinary }\end{array}$ & $<20 / \mathrm{NT} /<4$ & 79 & $3 \cdot 1$ \\
13 & $\begin{array}{c}\text { brucellosis } \\
\text { Treated } \\
\text { brucellosis }\end{array}$ & $\begin{array}{c}\text { surgeon } \\
\text { Apprentice }\end{array}$ & $<0 /<20 / 4$ & 56 & $7 \cdot 2$ \\
& joiner & $20 / \mathrm{NT} /<4$ & 78 & $3 \cdot 0$ \\
\hline
\end{tabular}

activity of infection, but it may at least serve to indicate brucellosis as a possible diagnosis requiring careful clinical assessment, despite absent or low serum antibody. Cases 13 and 14 both had clearly had episodes of active infection within the preceding 5 years. Assessment of their present illness is still under consideration.

The leukocyte migration inhibition test deserves further study. It may well yield much the same information as the brucellin skin test, but is more convenient as an out-patient procedure in that a result can be obtained without requiring two visits by the patient. Moreover, the test can be repeated as often as is desired without any possibility of altering the immune status of the patient by repeated small antigenic stimuli.

\section{Acknowledgments}

We are glad to acknowledge our indebtedness to Dr J. J. Hamblin of the General Hospital, Southend, Dr Alan Rycroft of the Public Health Laboratory, Southend, and Dr Noel
Newman, Medical Officer of Health, Frome R.D., for their kindness in providing the material basis for the case history quoted.

\section{References}

Henderson, R.J. \& Hill, D.M. (1972) Subclinical brucella infection in man. British Medical Journal, 2, 154.

PAYNe, D.J.H. (1972) Personal communication.

Pearson, A.D., Scarfe, S. \& Morgan, T.A. (1973) Evidence of a pattern in the variable host response to brucella in man. Lancet, i, 593.

REPORT (1961) Serological reagents for bacteriological diagnosis. Monthly Bulletin of the Ministry of Health and Public Health Laboratory Service, 20, 134.

SoBoRG, M. (1970) In vitro demonstration of microbial cellular hypersensitivity in man. Proceedings of the Royal Society of Medicine, 63, 903.

SoborG, M. (1971) In: Immunology of the Liver (Ed. by M. Smith). Davis, Philadelphia.

Takeshi Yoshida, Janeway, C.A. JR \& Paul, W.E. (1972) Activity of migration inhibitory factor in the absence of antigen. Journal of Immunology, 109, 201.

Wallis, H.R.E. (1959) Brucellosis in England. O'Connor, London. 